\title{
Pengaruh Model Pembelajaran Inkuiri Terbimbing Berbantuan Video Terhadap Hasil Belajar IPA
}

\author{
*Ni Kt. Dewi Muliani ${ }^{1}$, I Md. Citra Wibawa ${ }^{2}$ \\ 1,2 Jurusan Pendidikan Guru Sekolah Dasar, FIP, Universitas Pendidikan Ganesha Singaraja, Indonesia
}

\section{A R T I C L E I N F O}

Article history:

Received 10 November 2018

Received in revised form 09 December 2018

Accepted 15 January 2019

Available online 25

February 2019

\section{Kata Kunci: \\ hasil belajar IPA, inkuiri, video}

Keywords:

science learning result, inquiry, video

\begin{abstract}
A B S T R A K
Hasil belajar IPA SD dengan model pmebelajaran konvensional rendah.Penelitian ini bertujuan untuk mengetahui perbedaan yang signifikan hasil belajar IPA antara kelompok siswa yang dibelajarkan dengan menggunakan model pembelajaran inkuiri terbimbing berbantuan video dan kelompok siswa yang dibelajarkan dengan menggunakan pembelajaran konvensional pada siswa kelas V SD. Jenis penelitian ini adalah penelitian eksperimen semu. Populasi penelitian ini berjumlah 82 siswa dan sampel berjumlah 38 siswa. Data hasil belajar IPA dikumpulkan menggunakan metode tes obyektif. Data dianalisis menggunakan analisis statistik deskriptif dan statistik inferensial (uji-t polled varians). Hasil penelitian menunjukkan bahwa terdapat perbedaan yang signifikan hasil belajar IPA antara kelompok siswa yang dibelajarkan dengan menggunakan model pembelajaran inkuiri terbimbing berbantuan video dan kelompok siswa yang dibelajarkan dengan menggunakan pembelajaran konvensional (thitung=
\end{abstract} $5,24>$ tabel $=2,042)$. Rata-rata hasil belajar IPA kelompok eksperimen lebih besar daripada kelompok kontrol $(22,82>17)$, jadi model pembelajaran inkuiri terbimbing ini berpengaruh terhadap hasil belajar IPA siswa kelas V SD.

\section{A B S T R A C T}

This study is aimed to know the significant difference of science learning result between a group of students which is taught using guided inquiry based learning model aided by video and a group of students which is taught using conventional learning in the seventh grade of elementary school students. The type of this study is quasi experimental research. The amount of data population of this research is 82 students and the amount of the sample is 38 students. The result of this research data of Science course is compiled using objective test method. The data analysis used are descriptive statistic and inferential statistic (test-t polled variants). The result of this research indicates that there is a significant difference on the science learning result between the group of students which is taught using guided inquiry based learning method aided by video and the group of students which is taught using conventional learning ( $t$ arithmetic $=5,24>t$ table $=2,042$ ). The average result of Science learning on experiment group is bigger than the control group (22,82 > 17), hence this guided inquiry based learning model has a significant influence toward the science learning result in the seventh grade of elementary school.

\section{Pendahuluan}

Berorientasi pada perkembangan Ilmu Pengetahuan dan Teknologi (IPTEK) yang pesat, pendidikan menjadi modal awal untuk membentuk manusia yang mampu bersaing di era globalisasi. Tingkat Ilmu Pendidikan dan Teknologi (IPTEK) yang dicapai oleh suatu bangsa biasanya dipakai sebagai tolak ukur untuk melihat sejauh mana perkembangan dan kemajuan bangsa tersebut. Terlebih lagi pada era globalisasi ini kemajuan suatu bangsa sangat ditentukan oleh sumber daya manusia yang berkualitas. Salah satu sarana untuk meningkatkan kualitas SDM yaitu melalui pendidikan. Melalui proses pendidikan yang dilakukan, pertumbuhan, pembentukan dan perkembangan kepribadian serta kemampuan dan kecerdasan intelektual seseorang terbentuk.

Menurut Undang-Undang No. 20 Tahun 2003 tentang Sistem Pendidikan Nasional menyatakan bahwa, "pendidikan adalah usaha sadar dan terencana untuk mewujudkan suasana belajar dan proses

Copyright (c) Universitas Pendidikan Ganesha. All rights reserved. 
pembelajaran yang aktif agar siswa mampu mengembangkan potensi dalam dirinya untuk memiliki kekuatan spiritual keagamaan, pengendalian diri, kepribadian, kecerdasan, akhlak mulia, serta keterampilan yang diperlukan dirinya, masyarakat, bangsa dan Negara"(Kemendikbud, 2003) Terkait dengan pengertian tersebut maka pendidikan tidak hanya mengembangkan intelektual manusia saja, namun pendidikan berusaha mengembangkan kepribadian dan kemampuan manusia dalam aspek kognitif, afektif, dan psikomotor.Pendidikan memiliki peranan yang sangat penting dalam kehidupan berbangsa dan bernegara, yaitu untuk menjamin kelangsungan kehidupan dan perkembangan bangsa itu sendiri. Hal ini sebagaimana tercantum dalam Undang-Undang Nomor 20 tahun 2003 Tentang Tujuan Pendidikan Nasional, pasal 3 yang berbunyi, "pendidikan untuk mengembangkan kemampuan dan membentuk watak serta peradaban bangsa dalam rangka mencerdaskan kehidupan bangsa, mengembangkan potensi peserta didik agar menjadi manusia yang beriman dan bertaqwa kepada Tuhan Yang Maha Esa, berakhlak mulia, sehat, berilmu, cakap, kreatif, mandiri, dan menjadi warga Negara yang demokratis serta bertanggung jawab".

Untuk mencapai tujuan tersebut telah banyak upaya yang dilakukan oleh pemerintah agar dapat meningkakan kualitas pendidikan. Beberapa upaya yang telah dilakukan pemerintah, seperti penyempurnaan kurikulum, penyediaan sarana dan prasarana, peningkatan kualitas guru SD melalui program Pendidikan Profesi Guru (PPG), pengadaan bahan ajar dan buku referensi, dan pelatihanpelatihan (workshop) bagi para guru. Usaha tersebut dilakukan oleh pemerintah untuk menghasilkan sumber daya manusia yang berkualitas dan mampu bersaing di era globalisasi. Berkaitan dengan tuntutan untuk meningkatkan kualitas sumber daya manusia, maka kualitas pendidikan perlu ditingkatkan pada semua mata pelajaran termasuk mata pelajaran Ilmu Pengetahuan Alam.Ilmu Pengetahuan Alam (IPA) merupakan salah satu mata pelajaran dari lima mata pelajaran yang wajib dikuasai oleh siswa Sekolah Dasar. "IPA adalah ilmu yang mempelajari peristiwa-peristiwa yang terjadi di alam" (Sudana, 2016:2). Pembelajaran IPA di SD bertujuan untuk mengembangkan pengetahuan dan pemahaman konsep-konsep IPA yang bermanfaat dan dapat diterapkan dalam kehidupan sehari-hari, mengembangkan rasa ingin tahu, meningkatkan sikap mandiri dan kesadaran untuk berperan serta dalam memelihara, menjaga, dan melestarikan lingkungan alam serta meningkatkan kesadaran untuk menghargai alam dan segala keteraturannya sebagai salah satu ciptaan Tuhan (Susanto, 2013). Pembelajaran IPA di Sekolah Dasar sebaiknya memberikan kebebasan siswa untuk membuat atau menafsirkan suatu hal dalam kegiatan pembelajarannya untuk merancang dan menemukan sesuatu secara mandiri. Pembelajaran IPA diharapkan mampu dipahami dengan baik oleh siswa agar siswa mampu bekerja dan berkarya menemukan suatu hal secara mandiri dan bermakna.

Namun, kenyataannya di lapangan pembelajaran IPA belum mencerminkan kegiatan yang mandiri, bermakna dan menyenangkan. Hal ini ditunjukkan dari pembelajaran yang masih kurang variatif serta kecenderungan menerapkan model pembelajaran dengan paradigma pembelajaran lama yaitu guru sebagai pusat pembelajaran (teacher center). Hal tersebut menyebabkan proses pembelajaran kurang bermakna dan siswa cenderung pasif. Guru jarang menggunakan media video didalam proses pembelajaran IPA, guru juga jarang melakukan kegiatan yang memungkinkan siswa melakukan kegiatan penemuan seperti praktikum, sehingga cenderung tidak dapat mengembangkan keterampilan proses sains pada diri siswa. Padahal teori atau materi yang dibahas perlu dipraktikkan agar siswa dapat menemukan konsep dari materi tersebut secara mandiri. Contohnya pada materi hubungan antara gaya, gerak, dan energi, siswa akan memahami hubungan ketiganya melalui percobaan gaya gravitasi, gaya gesek dan gaya magnet. Namun pada kenyataannya siswa lebih banyak mendengar dan menulis yang menyebabkan isi pelajaran sebagai sebuah hafalan sehingga siswa tidak memahami konsep sebenarnya. Akibatnya informasi yang diperoleh siswa hanya mampu diingat dalam jangka waktu yang singkat.

Hasil observasi juga menunjukkan terdapat beberapa kelemahan-kelemahan dalam pembelajaran IPA yang dilakukan, (1) siswa terlihat mengalami kebosanan yang ditunjukkan dengan terdapat beberapa siswa yang pandangannya tidak fokus, mengobrol, dan bermain dengan teman sebangku ketika meteri pelajaran IPA dijelaskan oleh guru, (2) siswa tidak berperan aktif dalam mengontruksi pengetahuannya saat proses pembelajaran berlangsung, (3) siswa jarang mendapat kesempatan untuk mengimplementasikan penemuan konsep yang diperoleh sehingga pengetahuan yang didapatkan siswa menjadi kurang bermakna. Di dalam proses pembelajaran di kelas, guru hanya memberikan cerita di dalam kelas tanpa memfasilitasi siswa untuk bertanya mengenai permasalahan yang dihadapi oleh siswa pada saat melaksanakan proses pembelajaran. Pembelajaran yang dilakukan oleh guru cenderung hanya memberikan materi kepada siswa dilanjutkan dengan soal-soal tanpa diberikan bimbingan saat siswa melakukan pembelajaran. Hal ini disebabkan karena guru merasa kekurangan waktu mengajar dengan materi yang cukup banyak serta guru masih minim dengan penggunaan model pembelajaran yang inovatif, bervariasi dan menarik bagi siswa. Sehingga siswa menjadi kurang aktif, kurang percaya diri dan cepat bosan dalam belajar. Hal ini akan berpengaruh pada hasil belajar siswa yang cenderung rendah. 
Terdapat beberapa kelemahan-kelemahan dalam pembelajaran IPA yang dilakukan (1) siswa terlihat mengalami kebosanan yang ditunjukkan dengan terdapat beberapa siswa yang pandangannya tidak fokus, mengobrol, dan bermain dengan teman sebangku ketika meteri pelajaran IPA dijelaskan oleh guru, (2) siswa tidak berperan aktif dalam mengontruksi pengetahuannya saat proses pembelajaran berlangsung, (3) siswa jarang mendapat kesempatan untuk mengimplementasikan penemuan konsep yang diperoleh sehingga pengetahuan yang didapatkan siswa menjadi kurang bermakna dan akan berpengaruh pada hasil belajar siswa yang cenderung rendah. Temuan itu dibuktikan dari pencatatan dokumen mengenai hasil UAS (Ulangan Akhir Semester) mata pelajaran IPA siswa kelas V pada semester I tahun pelajaran 2017/2018 masih rendah. Diketahui jumlah siswa kelas V di Gugus IV Kecamatan Baturiti adalah 95 orang. Terlihat bahwa jumlah siswa yang mencapai KKM lebih sedikit yaitu 40 orang atau setara dengan $42 \%$ dari pada siswa yang belum mencapai KKM yaitu 55 orang atau setara dengan $58 \%$. Hal ini membuktikan bahwa penguasaan materi IPA siswa di Gugus IV Kecamatan Baturiti cenderung rendah atau belum mencapai kriteria ketuntasan klasikal karena setiap kelas V di Gugus IV Kecamatan Baturiti belum terdapat $\geq 85 \%$ siswa yang telah mencapai KKM.

Satu model pembelajaran untuk mata pelajaran IPA yang direkomendasikan oleh pakar untuk meningkatkan keterampilan proses sains siswa adalah model pembelajaran inkuiri terbimbing, karena model pembelajaran inkuiri terbimbing menekankan pada proses penemuan sebuah konsep sehingga muncul sikap ilmiah pada diri siswa. Siswa SD memiliki sifat yang aktif, sifat ingin tahu yang besar, terlibat dalam suatu situasi secara utuh dan reflektif terhadap suatu proses dan hasil-hasilnya yang ditemukan (Rahmani, 2016). model pembelajaran yang memberi fasilitas kepada siswa untuk merancang dan menemukan jawaban-jawaban secara langsung dari pertanyaan-pertanyaan/permasalahan yang diajukan guru (model pembelajaran inkuiri terbimbing). Berpikir kritis merupakan kemampuan yang akan diukur dalam penelitian ini yang diupayakan melalui model pembelajaran inkuiri terbimbing dalam pembelajaran IPA di SD khususnya pada materi energi bunyi (Kurnia, 2016). Model pembelajaran inkuiri terbimbing merupakan salah satu model pembelajaran yang tepat diterapkan pada kondisi kelas yang kemampuan peserta didiknya bervariasi. Model pembelajaran inkuiri terbimbing (guided inquiry) adalah model pembelajaran yang berpusat pada peserta didik, peserta didik juga dilatih mengembangkan kemampuan berpikir, peserta didik dilatih berpikir kritis. Selain itu, dapat membangkitkan gairah belajar pada peserta didik (Budi, 2017). Metode inkuiri adalah metode pembelajaran yang langkahnya siswa merumuskan masalah, mendesain eksperimen, mengumpulkan dan menganalisis data sampai mengambil keputusan sendiri. Metode inkuiri harus memenuhi empat kriteria ialah kejelasan, kesesuaian, ketepatan dan kerumitannya. Siswa benar-benar ditempatkan sebagai subjek yang belajar. Peranan guru dalam pembelajaran dengan metode inkuiri adalah sebagai pembimbing dan fasilitator. Tugas guru adalah memilih masalah yang perlu disampaikan kepada kelas untuk dipecahkan (Nugroho, 2012).

Mengacu pada permasalahan di atas, guru hendaknya mampu memilih metode dan model pembelajaran yang sesuai dengan kondisi dan karakteristik materi pembelajaran IPA yang akan dibelajarkan. Guru juga harus mampu memilih model pembelajaran yang dapat membuat siswa aktif dalam melaksanakan pembelajaran. Penggunaan media pembelajaran juga sangat bermanfaat bagi siswa karena dalam penyampaian materi dari guru kepada siswa lebih mudah dan diyakini mampu bermanfaat bagi siswa pada saat proses pembalajaran. Peran guru sangat penting untuk membimbing siswa melakukan kegiatan pembelajaran dengan jalan mengajukan pertanyaan-pertanyaan awal dan mengarahkan siswa pada suatu diskusi. Salah satu solusi yang dapat ditawarkan adalah menggunakan model pembelajaran inkuiri terbimbing dalam proses pembelajaran. Menurut Gulo (dalamTrianto, 2007:135) menyatakan pembelajaran inkuiri adalah suatu rangkaian kegiatan belajar yang melibatkan secara maksimal seluruh kemampuan siswa untuk mencari dan menyelidiki sistem otomatis, kritis, logis, analitis sehingga mereka dapat merumuskan sendiri penemuannya dengan penuh percaya diri. Sedangkan menurut (Dewi, 2012) menyatakan model pembelajaran inkuiri terbimbing merupakan model pembelajaran yang menekankan pada proses penemuan sebuah konsep dengan bimbingan guru sebagai fasilitator sehingga muncul sikap ilmiah pada diri siswa. Berdasarkan pendapat yang telah dikemukakan, dapat disimpulkan bahwa model pembelajaran inkuiri terbimbing adalah salah satu model pembelajaran yang mengutamakan proses penemuan dalam proses pembelajaran untuk menemukan sebuah konsep dengan bimbingan guru. Model ini berupaya menanamkan dasar-dasar berpikir ilmiah pada diri siswa, sehingga dalam proses pembelajaran ini siswa lebih banyak belajar mandiri dimana guru berperan sebagai pembimbing, fasilitator dan motivator. Pembelajaran inkuiri memiliki beberapa tahapan yakni menetapkan masalah, merumuskan hiposesis, melakukan percobaan/eksperimen, mengolah dan menganalisis data, menguji hipotesis hingga membuat kesimpulan. Model pembelajaran ini akan menantang siswa untuk senantiasa aktif selama proses pembelajaran sekaligus mendorong siswa untuk mengoptimalkan keterampilan dan kemampuannya (Wahyuni, 2016). 
Dalam mendukung model pembelajaran yang sudah relevan digunakan, maka dalam penelitian ini menggunakan bantuan video pembelajaran. Menurut Mahadewi, L. P. P., (2012:3) menyatakan bahwa "video diartikan sebagai segala format media elektronik yang digunakan untuk merangsang pikiran, perasaan, dan minat siswa untuk belajar melalui penayangan video atau gagasan, pesan dan informasi gambar-gambar bergerak". Video pembelajaran juga memiliki peranan yang sangat penting terutama dalam pembelajaran karena dapat menarik perhatian siswa sehingga dapat menumbuhkan motivasi belajar, memperjelas makna bahan pengajaran sehingga mudah dipahami siswa, metode pengajaran lebih bervariasi serta siswa lebih banyak melakukan kegiatan belajar.

Berbagai hasil penelitian telah membuktikan keberhasilan penerapan model pembelajaran inkuiri terbimbing dan video pembelajaran dalam meningkatkan hasil belajar IPA siswa. Hasil penelitian yang dilakukan oleh Milawati (2013) pada siswa kelas IV SD Negeri di Gugus V Abiansemal menyatakan bahwa terdapat perbedaan yang signifikan hasil belajar IPA antara kelompok siswa yang dibelajarkan dengan model inkuiri terbimbing berbasis proyek dan kelompok siswa yang dibelajarkan dengan pembelajaran konvensional. Kelompok siswa yang dibelajarkan dengan inkuiri terbimbing berbasis proyek memiliki nilai rata-rata hasil belajar IPA lebih baik daripada kelompok siswa yang dibelajarkan dengan pembelajaran konvensional. Selain itu penelitian yang serupa juga pernah dilakukan oleh Kartika (2017) pada siswa kelas V SD di Gugus II Kecamatan Sukasada menyatakan bahwa terdapat perbedaan yang signifikan hasil belajar antara kelompok siswa yang dibelajarkan dengan model pembelajaran inkuiri terbimbing berbantuan peta pikiran dan motivasi berprestasi dengan kelompok siswa yang tidak dibelajarkan dengan model pembelajaran inkuiri terbimbing berbantuan peta pikiran dan motivasi berprestasi. Kelompok siswa yang dibelajarkan dengan inkuiri terbimbing berbantuan peta pikiran dan motivasi berprestasi memiliki nilai rata-rata hasil belajar IPA lebih baik daripada kelompok siswa yang tidak dibelajarkan dengan inkuiri terbimbing berbantuan peta pikiran dan motivasi berprestasi.

Berdasarkan uraian di atas, dilakukan penelitian yang bertujuan untuk mengetahui perbedaan hasil belajar IPA antara kelompok siswa yang dibelajarkan menggunakan model pembelajaran inkuiri terbimbing berbantuan video dan kelompok siswa yang dibelajarkan menggunakan pembelajaran konvensional pada siswa kelas V SD di Gugus IV KecamatanBaturiti tahun pelajaran 2017/2018.

\section{Metode}

Jenis penelitian ini adalah penelitian eksperimen. Penelitian eksperimen merupakan penelitian yang bertujuan untuk menguji keefektifan suatu teori/konsep/model dengan cara menerapkan (treatment) pada satu kelompok subjek penelitian dengan menggunakan kelompok pembanding yang bisa disebut kelompok kontrol (Agung, 2014). Dalam penelitian ini unit eksperimennya berupa kelas, sehingga penelitian yang digunakan adalah penelitian eksperimen semu (quasi eksperiment), karena tidak semua variabel yang muncul dan kondisi eksperimen dapat dikontrol secara ketat (full randomize). Rancangan penelitian ini yaitu non-equivalent post test only control group desain(Agung, 2014).

Populasi penelitian ini adalah siswa kelas V di Gugus IV Kecamatan Baturiti Kabupaten Tabanan Tahun Pelajaran 2017/2018 yang berjumlah 82 orang. Sampel dalam penelitian ini ditentukan dengan teknik random sampling yaitu pengambilan anggota dilakukan secara acak tanpa memperhatikan strata yang ada dalam populasi dan anggota populasi memiliki hasil belajar yang sudah setara. Sebelum pengundian sampel penelitian, terlebih dahulu dilakukan uji kesetaraan pada masing-masing kelas. Uji kesetaraan menggunakan analisis varians satu jalur (ANAVA A). Jika angka signifikansi hitung kurang dari 0,05 maka kelas tersebut tidak setara. Sedangkan jika angka signifikansi hitung lebih ebsar dari 0,05 maka kelas tersebut setara.Berdasarkan hasil uji kesetaraan yang telah dilakukan didapatkan hasil bahwa seluruh siswa kelas V SD di Gugus IV Kecamatan Baturiti setara. Pengundian sampel dilakukan sebanyak dua kali, yaitu (1) menentukan sampel, dan (2) menentukan kelompok eksperimen dan kelompok kontrol. Setelah dilakukan uji kesetaraan dan dilakukan pengundian sebanyak dua kali, sampel penelitian ini adalah siswa kelas V SD Negeri 2 Angseri yang berjumlah 17 orang yang digunakan sebagai kelompok eksperimen dan siswa kelas V SD Negeri 3 Angseri yang berjumlah 21 orang yang digunakan sebagai kelompok kontrol.

Penelitian ini melibatkan dua variabel, yaitu variabel bebas dan variabel terikat. Variabel bebas yaitu model pembelajaran inkuiri terbimbing berbantuan video. Model pembelajaran inkuiri terbimbing berbantuan video diterapkan pada kelas eksperimen dan pada kelas kontrol menerapkan pembelajaran konvensional. Pembelajaran dilakukan sebanyak delapan kali pertemuan yaitu tujuh kali kegiatan pembelajaran dan satu kali post-test. Variabel terikat adalah hasil belajar IPA yang diukur melalui posttest.

Data yang dikumpulkan dalam penelitian ini adalah data hasil belajar IPA yang dikumpulkan dengan instrumen berupa tes pilihan ganda. Hasil belajar IPA yang diukur adalah pada aspek kognitif. 
Instrumen yang digunakan telah melalui uji validasi. Uji validasi instrumen hasil belajar IPA meliputi uji validitas isi, uji validitas butir, uji reliabilitas, daya beda butir tes dan uji tingkat kesukaran tes. Setelah melakukan validasi instrumen, dari 40 butir pertanyaan pada tes hasil belajar IPA, terdapat 10 soal yang tidak valid, berada dalam taraf sukar dan daya beda kurang baik sehingga pertanyaan yang digunakan untuk post test sebanyak 30 butir.

Data yang telah diperoleh kemudian dianalisis. Analisis data yang digunakan dalam penelitian ini yaitu analisis statistik deskriptif (mean, median, modus, standar deviasi, varian) dan statistik inferensial (uji prasyarat dan uji hipotesis). Uji prasyarat yang dilakukan yaitu uji normalitas sebaran data dan uji homogenitas varians. Uji normalitas sebaran data dilakukan untuk mengetahui data berasal dari populasi yang berdistribusi normal atau tidak dengan menggunakan rumus Chi-Square. Uji homogenitas varians dilakukan untuk mengetahui kehomogenan dari data hasil belajar IPA dengan menggunakan rumus uji Fisher. Pengujian hipotesis dilakukan dengan uji-t polled varians(Koyan, 2012).

\section{Hasil dan Pembahasan}

Data hasil penelitian dianalisis sehingga diperoleh mean, median, modus, varians serta standar deviasi dari tiap-tiap kelompok data yang disajikan seperti Tabel 1.

Tabel 1. Rangkuman Perhitungan Data Hasil Belajar IPA Siswa

\begin{tabular}{ccc}
\hline \multirow{2}{*}{ Statistik Deskriptif } & \multicolumn{3}{c}{ Hasil Belajar IPA Siswa } \\
& Kelompok Eksperimen & Kelompok Kontrol \\
\hline Mean & 22,82 & 17 \\
Median & 23,6 & 16,76 \\
Modus & 23,9 & 16,25 \\
Varians & 24,94 & 21,35 \\
Standar Deviasi & 4,99 & 4,62 \\
Skor Maksimum & 30 & 25 \\
Skor Minimum & 13 & 7 \\
\hline
\end{tabular}

Dari Berdasarkan hasil analisis deskriptif pada tabel 1, hasil belajar IPA menunjukkan skor ratarata hasil belajar IPA kelompok eksperimen lebih tinggi dibandingkan dengan skor rata-rata kelompok kontrol. Tinjauan ini didasarkan pada rata-rata skor dan kecenderungan skor hasil belajar IPA yang diperoleh kedua kelompok.Data hasil belajar IPA pada kelompok siswa yang dibelajarkan dengan model pembelajaran inkuiri terbimbing berbantuan video diperoleh melalui tes hasil belajar terhadap 17 orang siswa. Berdasarkan data hasil belajar IPA siswa yang diperoleh melalui tes hasil belajar terhadap 17 orang siswa pada kelompok eksperimen menunjukkan bahwa skor terendah adalah 13 dan skor tertinggi adalah 30. Dapat dideskripsikan mean $(\mathrm{M})=22,82$, median $(\mathrm{Md})=23,6$, modus $(\mathrm{Mo})=23,9$, varians $\left(\mathrm{s}^{2}\right)=24,94$, dan standar deviasi $(\mathrm{s})=4,99$. Sebaran data kelompok eksperimen menunjukkan bahwa sebagian besar skor hasil belajar IPA siswa cenderung tinggi dengan (Mo $>\mathrm{Md}>\mathrm{M}$ ).

Hasil belajar IPA menunjukkan skor rata-rata hasil belajar IPA pada kelompok kontrol adalah 17 berada pada kategori sedang. Sebaran data kelompok kontrol menunjukkan bahwa sebagian besar skor hasil belajar IPA siswa cenderung rendah dengan $(\mathrm{M}>\mathrm{Md}>\mathrm{Mo})$. Diperoleh mean $(\mathrm{M})=17$, median $(\mathrm{Md})$ $=16,76$, modus $(\mathrm{Mo})=16,25$. Gambaran data hasil belajar IPA pada kelompok kontrol disajikan ke dalam bentuk kurva poligon pada Gambar 2.

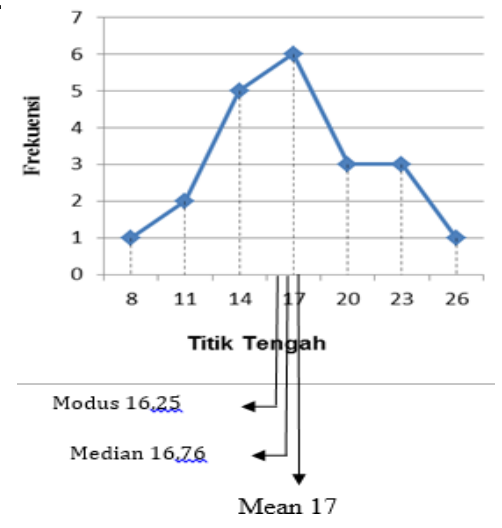

Gambar 2

Kurva Poligon Hasil Belajar Kelompok Kontrol 
Berdasarkan pada hasil analisis data di atas tampak bahwa hasil belajar IPA siswa pada kelompok eksperimen lebih baik dibandingkan dengan hasil belajar IPA siswa pada kelompok kontrol. Hasil analisis uji normalitas sebaran data dengan teknik Chi-Square terhadap dua jenis data, yaitu data hasil belajar IPA pada kelompok siswa yang dibelajarkan dengan model pembelajaran inkuiri terbimbing berbantuan video dan hasil belajar IPA pada kelompok siswa yang dibelajarkan dengan pembelajaran konvensional yang masing-masing variabel memiliki angka signifikansi lebih besar dari 0,05 sehingga sebaran data berdistribusi normal.

Hail analisis uji homogenitas varians dilakukan menggunakan rumus uji Fisher (F) pada kedua kelompok menunjukkan bahwa angka signifikansi lebih besar dari 0,05 sehingga varians kedua kelompok homogen.

Hasil uji hipotesis menggunakan Uji-t sampel independen menunjukkan bahwa nilai $t_{\text {hitung }}$ sebesar

5,24. Sedangkan $t_{\text {tabel }}$ dengan $\mathrm{db}=36$ dan taraf signifikansi 5\% adalah 2,042. Hal ini berarti $t_{\text {hitung }}$ lebih besar dari $t_{\text {tabel }}\left(t_{\text {hitung }}>t_{\text {tabel }}\right)$ sehingga $\mathrm{H}_{0}$ ditolak atau $\mathrm{H}_{1}$ diterima. Dengan demikian, dapat diinterpretasikan bahwa terdapat perbedaan yang signifikan hasil belajar IPA antara kelompok siswa yang dibelajarkan dengan model pembelajaran inkuiri terbimbing berbantuan video dan kelompok siswa yang dibelajarkan dengan pembelajaran konvensional.

Berdasarkan deskripsi data hasil penelitian, hasil belajar IPA kelompok siswa yang dibelajarkan dengan model pembelajaran inkuiri terbimbing berbantuan video lebih baik dibandingkan dengan kelompok siswa yang dibelajarkan dengan pembelajaran konvensional. Hal ini ditunjukkan dari nilai ratarata kelompok eksperimen adalah 22,82 lebih besar dari nilai rata-rata kelompok kontrol adalah 17. Terdapat beberapa faktor yang menyebabkan hasil belajar IPA kelompok siswa yang dibelajarkan dengan model pembelajaran inkuiri terbimbing berbantuan video lebih baik dibandingkan dengan hasil belajar IPA kelompok siswa yang dibelajarkan dengan pembelajaran konvensional yaitu sebagai berikut.

Faktor pertama, proses pembelajaran dengan model pembelajaran inkuiri terbimbing berbantuan video memberikan kesempatan kepada siswa untuk menggali pengetahuannya secara mandiri. Pengetahuan siswa akan tergali melalui tayangan video dan serangkaian pertanyaan yang ditanggapi oleh siswa. Hal ini nampak pada saat siswa memperhatikan tayangan video mengenai cahaya dapat menembus benda bening maupun video lainnya selama proses pembelajaran dengan model pembelajaran inkuiri terbimbing berbantuan video, siswa terlihat sangat antusias memperhatikan tayangan video yang disajikan kemudian siswa mencatat hal-hal penting yang ditemukan dalam video tersebut dan membuat sebuah hipotesis. Tayangan video pembelajaran dapat menarik perhatian siswa sehingga siswa termotivasi untuk belajar dan membantu siswa memahami suatu permasalahan IPA yang harus diselesaikan serta pemahaman siswa terhadap materi yang dipelajari akan menjadi lebih baik. Hal ini juga sejalan dengan yang dikemukakan oleh Mahadewi, L. P. P., (2012) bahwa dengan adanya media video dalam proses pembelajaran dapat menarik perhatian siswa sehingga dapat menumbuhkan motivasi siswa untuk belajar dan dapat memperjelas makna bahan pengajaran sehingga mudah dipahami siswa.

Faktor kedua, model pembelajaran inkuiri terbimbing berbantuan video akan memberikan kesempatan kepada siswa untuk memecahkan masalah IPA melalui kegiatan penyelidikan sehingga hasil yang ditemukan tidak sekedar diingat melainkan dipahami dan mampu diaplikasikan dalam kehidupan sehari-hari karena siswa aktif membangun pemahamannya secara mandiri. Jawaban dari hipotesis yang diajukan siswa didapat bukan dari hasil mengingat fakta atau konsep-konsep melainkan mencari jawaban atas masalah yang diberikan dari hasil menemukan sendiri. Pemahaman yang dibangun dan ditemukan sendiri oleh siswa akan menjadi pengetahuan yang bermakna. Tinjauan ini sejalan dengan Suastra, (2009:37) menyatakan bahwa "belajar berarti membentuk makna. Makna diciptakan oleh siswa dari apa yang mereka lihat, dengar, rasakan, dan alami”. Pengetahuan akan bermakna bila dicari dan ditemukan oleh siswa itu sendiri serta dapat diingat dalam jangka waktu yang lama. Selanjutnya Widyatmoko (dalamDewi, 2012) menyatakan bahwa, pengetahuan yang diperoleh dengan menemukan sendiri akan berdampak baik pada diri siswa diantaranya pengetahuan itu bertahan lama, dengan menemukan sendiri akan berdampak pada hasil belajar yang lebih baik dan meningkatkan penalaran siswa untuk berpikir secara bebas.

Faktor ketiga, siswa yang didorong bekerja secara berkelompok untuk melakukan kegiatan diskusi sebelum dan sesudah memecahkan masalah akan menambah keyakinan siswa terhadap hasil pemikiran dan pemahamannya. Di dalam kegiatan diskusi, siswa akan melakukan kegiatan tanya jawab terkait hasil penyelidikan bersama teman kelompoknya. Kegiatan tanya jawab akan melatih kemampuan siswa dalam menyampaikan gagasan dan memberikan respon terhadap suatu masalah. Tinjauan ini sejalan dengan pendapat yang dikemukakan oleh Sumatowa (2006:5) yang menyatakan bahwa, "melalui 
kegiatan bertanya anak akan berlatih menyampaikan gagasan dan memberikan respon yang relevan terhadap suatu masalah yang dimunculkan".

Faktor keempat, siswa diarahkan untuk memecahkan suatu masalah dengan menerapkan konsep yang ditemukan pada saat proses kegiatan penyelidikan dan negosiasi makna. Suatu latihan dan pemecahan masalah akan memberikan kesempatan kepada siswa untuk menerapkan konsep-konsep yang dimilikinya,. Mengkaji hasil percobaan yang dilakukan, mengolah informasi yang didapat melalui diskusi dan pemecahan masalah akan melatih siswa untuk kreatif, berpikir kritis dan merealisasikan pemikirannya sehingga siswa dapat membuat suatu kesimpulan. Menurut Orlich et.al (1998) (dalam Khushid \& Ansari, 2012)menyatakan, bahwa siswa mengembangkan kemampuan berpikir melalui observasi spesifik hingga membuat inferensi atau generalisasi.

Berbeda halnya dengan pembelajaran yang dilaksanakan dikelas kontrol yakni menggunakan pembelajaran konvensional yaitu pembelajaran yang biasa digunakan oleh guru dalam mengajar (tidak menggunakan model pembelajaran inkuiri terbimbing berbantuan video) dalam pembelajaran IPA. Dalam proses pembelajaran siswa cenderung pasif dalam menggali pengetahuannya. Pembelajaran yang dilaksanakan cenderung berpusat pada guru (teacher center). Dalam pembelajaran tersebut guru bertugas untuk mengirimkan apa yang diketahui guru kepada siswa. Tinjauan ini sejalan dengan pendapat yang dikemukakan oleh Wina (dalam (Dewi, 2012) menyatakan bahwa pembelajaran konvensional lebih menekankan kepada proses penyampaian materi secara verbal dari seorang guru kepada sekelompok siswa dengan maksud agar siswa dapat menguasai materi pelajaran secara optimal. Guru memegang peranan yang dominan dalam proses pembelajaran dan siswa tidak dituntut menemukan konsep-konsep IPA yang ada. Hal ini tentunya akan mengakibatkan ketidakbiasaan pada siswa dalam memperluas dan memperdalam pengetahuannya sehingga siswa menjadi pasif.

Hal tersebut sesuai dengan penelitian yang dilakukan oleh Milawati (2013) pada siswa kelas IV SD Negeri di Gugus V Abiansemal menyatakan bahwa terdapat perbedaan yang signifikan hasil belajar IPA antara kelompok siswa yang dibelajarkan dengan model inkuiri terbimbing dan kelompok siswa yang dibelajarkan dengan pembelajaran konvensional. Kelompok siswa yang dibelajarkan dengan inkuiri terbimbing memiliki nilai rata-rata hasil belajar IPA lebih baik daripada kelompok siswa yang dibelajarkan dengan pembelajaran konvensional. Penelitian yang serupa juga dilakukan oleh Kartika (2017) pada siswa kelas V SD di Gugus II Kecamatan Sukasada menyatakan bahwa terdapat perbedaan hasil belajar IPA antara kelompok siswa yang dibelajarkan dengan model pembelajaran inkuiri terbimbing berbantuan peta pikiran dan motivasi berprestasi dan kelompok siswa yang dibelajarkan dengan pembelajaran konvensional.

\section{Simpulan dan Saran}

Berdasarkan hasil penelitian dan pembahasan pengujian dari data yang diperoleh dapat disimpulkan bahwa, terdapat perbedaan yang signifikan hasil belajar IPA antara kelompok siswa yang dibelajarkan dengan model pembelajaran inkuiri terbimbing berbantuan video dan kelompok siswa yang dibelajarkan dengan pembelajaran konvensional, hal ini dapat ditunjukkan dari nilai rata-rata kelompok eksperimen adalah 22,82 lebih besar dari rata-rata kelompok kontrol adalah 17 dan terlihat dari $t_{\text {hitung }}$ diperoleh sebesar 5,24, sedangkan $t_{\text {tabel }}$ pada taraf signifikansi 5\% adalah 2,042. Hal ini berarti $t_{\text {hitung }}$ lebih besar dari $t_{\text {tabel }}\left(t_{\text {hitung }}>t_{\text {tabel }}\right)$ sehingga $\mathrm{H}_{0}$ ditolak atau $\mathrm{H}_{1}$ diterima. Sehingga model pembelajaran inkuiri terbimbing berbantuan video ini berpengaruh terhadap hasil belajar IPA siswa kelas V SD di Gugus IV Kecamatan Baturiti tahun pelajaran 2017/2018.

Saran yang dapat disampaikan berdasarkan penelitian yang telah dilakukan adalah sebagai berikut. (1) Bagi kepala sekolah hendaknya ikut memperkenalkan dan memberikan dorongan bagi guru-guru untuk menerapkan model pembelajaran inkuiri terbimbing berbantuan video yang dapat digunakan dalam meningkatkan kualitas pembelajaran agar siswa menjadi lebih aktif, 2) Bagi guru, dalam melaksanakan pembelajaran IPA agar memperoleh kualitas hasil belajar yang baik, maka disarankan untuk menggunakan atau menerapkan model pembelajaran inkuiri terbimbing berbantuan video. Guru hendaknya membuat sebuah pertanyaan yang mampu mengarahkan siswa untuk membuat suatu hipotesis terhadap suatu permasalahan IPA, (3) Bagi siswa hendaknya mampu mengikuti proses pembelajaran dengan menggunakan model pembelajaran inkuiri terbimbing berbantuan video dengan baik dan aktif dalam setiap kegiatan pembelajaran, (4) Bagi peneliti lain yang akan melakukan penelitian dengan model pembelajaran inkuiri terbimbing berbantuan video hendaknya diteliti pada kelas yang berbeda, dengan variabel lain dan jumlah sampel yang lebih banyak. 


\section{Daftar Rujukan}

Agung, A. A. G. (2014). Metodologi Penelitian Pendidikan. Malang: Aditya Media Publish.

Budi, B. (2017). Pengaruh Model Pembelajaran Inkuiri Terbimbing Terhadap Hasil Belajar Kognitif Peserta Didik Di Sma Negeri 01 Manokwari (Studi Pada Pokok Bahasan Kelarutan Dan Hasil Kali Kelar. Jurnal Nalar Pendidikan, 5(1), 21-30.

Dewi, N. L. (2012). engaruh Model Pembelajaran Inkuiri Terbimbing terhadap Sikap Ilmiah dan Hasil Belajar IPA. E-Journal Program Pascasarjana Universitas Pendidikan Ganesha Jurusan Pendidikan Dasar, 1(3), 235-244.

Kartika, N. M. D., \& Margunayasa, I. G. (2017). Pengaruh model pembelajaran inkuiri terbimbing berbantuan peta pikiran dan motivasi berprestasi terhadap hasil belajar IPA. Mimbar PGSD, 5(2).

Kemendikbud. (2003). Undang-Undang Nomor 20 Tahun 2003 tentang Sistem Pendidikan Nasional (SISDIKNAS). Jakarta: Kementrian Pendidikan dan Kebudayaan.

Khushid, F., \& Ansari, U. (2012). Effect of Innovative Teaching Strategies on Student's Performance. Global Journal Of Human Social Science Linguistics \& Education, 12(10).

Koyan, I. W. (2012). Statistika Terapan ( Teknik Analisis Data Kuantitatif). Singaraja: Universitas Pendidikan Ganesha.

Kurnia, A. (2016). Pengaruh Model Pembelajaran Inkuiri Terbimbing Terhadap Kemampuan Berpikir Kritis Siswa Pada Materi Energi Bunyi. Jurnal Pena Ilmiah, 1(1), 51-60.

Mahadewi, L. P. P., dkk. (2012). Media Video Pembelajaran. Singaraja: Undiksha.

Milawati, N. L. P. Y. (2013). Pengaruh model pembelajaran inkuiri terbimbing berbasis proyek terhadap hasil belajar ipa siswa kelas IV SD Negeri Gugus V Abiansemal. Mimbar PGSD, 1.

Nugroho, S. (2012). Pembelajaran IPA Dengan Metode Inkuiri Terbimbing Menggunakan Laboratorium Riil Dan Virtuil Ditinjau Dari Kemampuan Memori dan Gaya Belajar Siswa. . . Jurnal Inkuiri Issn, 1(3), 235-244.

Rahmani. (2016). Penerapan Model Pembelajaran Inkuiri Terbimbing Untuk Meningkatkan Keterampilan Proses Sains (Kps) Siswa Sekolah Dasar. Jurnal Pencerahan, 10(2), 74-80.

Suastra, I. W. (2009). Pembelajaran Sains Terkini. Singaraja: Undiksha.

Sudana, D. N. dkk. (2016). Pendidikan IPA SD. Singaraja: Undiksha.

Sumatowa, U. (2006). Bagaimana Membelajarkan IPA di Sekolah Dasar. Jakarta: Depdiknas.

Trianto. (2007). Model-model Pembelajaran Inovatif berorientai kontruktivistik. Jakarta: Prestai Pustaka.

Wahyuni, R. (2016). Pengaruh Model Pembelajaran Inkuiri Terbimbing dengan Metode Eksperimen terhadap Hasil Belajar Fisika Siswa Kelas XI IPA SMAN 2 Mataram Tahun Pelajaran 2016/2017. Jurnal Pendidikan Fisika Dan Teknologi, 2(4), 164-169. 